\title{
免疫応答制御分子研究の最前線
}

\author{
西田圭吾, ${ }^{*}, a$ 松田 $\quad$ 正 $^{b}$
}

\section{Frontiers in Researches of Immune Regulators}

\author{
Keigo Nishida*,a and Tadashi Matsuda ${ }^{b}$ \\ ${ }^{a}$ Laboratory for Cytokine Signaling, RIKEN Research Center for Allergy and Immunology; \\ 1-7-22 Suehiro-cho, Tsurumi-ku, Yokohama 230-0045, Japan: and ${ }^{b}$ Department of \\ Immunology, Graduate School of Pharmaceutical Sciences, Hokkaido University; \\ Kita 12-jo Nishi 6-chome, Kita-ku, Sapporo 060-0812, Japan.
}

免疫はわれわれが通常生きていくためには不可欠 なシステムである. そのシステムが破綻した場合, 感染症, 自己免疫疾患, アレルギーなどの様々な疾 患を患う。また，免疫学はまさに細胞生物学・分子 生物学といった学問を牽引してきたといっても過言 ではなく, 多くの先駆者的な免疫学者によって, 免 疫担当細胞の発見, サイトカインなどの免疫調節因 子や抗原受容体の発見, さらには細胞内の様々なシ グナル伝達分子の同定と制御機構の解明がなされて きた.これらの知見を基に, 抗体医薬品の開発がな され，一部の自己免疫疾患に関して，治療薬として 臨床に応用されてきている. しかしながら多くの免 疫疾患に対する医薬品は未開発であり，アレルギー 疾患・自己免疫疾患・感染症を克服するためにも, 免疫システムの成り立ちを分子から個体のレベルま で理解していくことが不可欠である.よつて, 免疫 学から得られた知見を基に創薬開発を行うことによ り, 免疫システムの人為的制御を達成できるものと 期待できる.

日本薬学会第 132 年会において企画されたシンポ ジウム『免疫応答制御分子研究の最前線』では免疫 応答制御に関与する分子群にフォーカスをあて，そ の調節機構に関して最新の知見を獲得しつつある若 手免疫学研究者にご講演頂いた. 具体的には，1）マ

a独立行政法人理化学研究所免疫・アレルギー科学総合 研究センターサイトカイン制御研究グループ（テ2300045 横浜市鶴見区未広町 $1-7-22), b$ 北海道大学大学 院薬学研究院創薬科学部門衛生化学研究室 (T0600812 札幌市北区北 12 条西 6 丁目)

*e-mail: nishida@ rcai.riken.jp

日本薬学会第 132 年会シンポジウム OS06 序文
スト細胞依存的なアレルギー応答における Gab2 分 子の活性化機構（理研 RCAI，西田圭吾），2）B 細 胞におけるカルシウムシグナル制御機構（大阪大学 IFReC, 松本真典, 馬場義裕)，3）C 型レクチン受 容体を介する免疫調節機構（九大生体防御医学研, 山崎 晶)，4）ITAM 受容体シグナル伝達と免疫 疾患 (佐賀大医，原 博満），5）LIM 分子による Th17 細胞分化の負の制御機構 (理研 RCAI, 田中 貴志), そして最後に，6）免疫応答における分子イ メージングの応用についての内容である（京大医 $\mathrm{AK}$ プロジェクト，戸村道夫）。これら免疫応答を 制御する新しい分子群とその機能に関する知見は免 疫システムの全体像を明らかにすることが期待され る.

本稿では講演内容に基づいた誌上シンポジウムと して, 制約された講演時間内ではカバーしきれなか つた部分を含んだ最新の研究成果をまとめて頂い た．オーガナイザーの西田は，マスト細胞依存的な アレルギー応答のアナフィラキシーに関して, アダ プター分子 Grb2-associated binder 2 (Gab2) を中 心として, 抗原受容体からヒスタミン遊離までの制 御機構の詳細について解説した. 松本・馬場両先生 には免疫担当細胞において重要なカルシウムシグ ナルに関与している stromal interaction molecule (STIM) 分子を中心として, その構造から機能に 至るまでの詳細を解説して頂き, 特に, 抑制性 B 細胞におけるサイトカインの調節機構, さらに, STIM が関与する脳春髄炎の抑制機構に関する最新 の知見を紹介して頂く，そして最後に，戸村先生に は近年, 生物学研究に導入されているイメージング 
技術の更なる進歩として，ユニークな光変換蛍光夕 ンパク質「カエデ」などを用いた免疫細胞動態・機 能の可視化による免疫系理解のためのアプローチに 関して執筆して頂いた。これらの解説はまさに応答
制御分子研究の最前線の知見であり, この誌上シン ポジウムが読者の方々のこの分野の理解の一助にな れば幸いである. 